\title{
A REVIEW OF THE DISTRIBUTION AND ECOLOGY OF BUCHONOMYIA THIENEMANNI FITTKAU (DIPTERA: CHIRONOMIDAE) INCLUDING A FIRST RECORD FOR RUSSIA
}

\author{
PATRICK ASHE ${ }^{1, *}$, JAMES P. O’CONNOR ${ }^{2}$, and DECLAN A. MURRAY 3 \\ 133 Shelton Drive, Terenure, Dublin 12, Ireland \\ 2 Emeritus Entomologist, National Museum of Ireland, Kildare Street, Dublin 2, Ireland \\ ${ }^{3}$ Freshwater Biodiversity, Ecology and Fisheries Research Group, School of Biology and Environmental Science, University College \\ Dublin, Belfield, Dublin 4, Ireland \\ * Corresponding author: patrick.ashe@upcmail.ie
}

\section{ABSTRACT}

Detailed and updated distribution records are provided for Buchonomyia thienemanni Fittkau throughout its known western Palaearctic range including Europe, North Africa and the Near East. Two subfossil pupal records from former (dried-up) river channels are included. The species is recorded from Russia for the first time. A review of the known ecology is provided. The species is believed to be ectoparasitic on a species of Trichoptera and a likely host is suggested.

Keywords: Chironomidae, Buchonomyia thienemanni, records, ecology, distribution

\section{Introduction}

Buchonomyia thienemanni was originally described as a new genus and species by Fittkau (1955) based on a single adult male specimen collected in the Wasserkuppe region of the River Fulda in Germany. Many years later adults were found at a second European locality - the River Flesk in S. W. Ireland (Murray 1976). Subsequently mature pupae were discovered and pupal exuviae and the adult female were described (Murray and Ashe 1981, 1985). Since then the ability to easily identify the pupal exuviae of $B$. thienemanni combined with the widespread use of drift nets in Europe (and adjoining areas) resulted in a rapid increase in the number of records and countries where the species is known from. Most records are based on pupal exuviae from drift or foam samples (which occasionally include drowned adults) as the flying adults and secretive larvae are much more elusive. The use of drift nets (to collect river foam) proved successful recently with the first records from the Czech Republic (Ashe et al. 2014).

Detailed data for all known records of $B$. thienemanni throughout its distribution range in the western Palaearctic are presented. Several new records are listed, including the first record from Russia, and more details are provided for some previously published records. Longitude and latitude data, not usually specified for the majority of published records, have been calculated where necessary and included for each specific site. Most of the records are recent but two are based on subfossil pupal fragments collected in sediments extracted from the dried-up former channels of large rivers.

Based on both larval and pupal features $B$. thieneman$n i$ is believed to be ectoparasitic on a species of Trichoptera (Ashe and O'Connor 2002) but the identity of the host species is unknown. However, based on both distribution and ecological data a likely host is now suggested.

\section{Distribution of Buchonomyia thienemanni}

The previous most easterly known European record was from Slovakia (Bitušík 1987). The new record from Russia, based on pupal exuviae from a river to the west of Moscow, considerably extends the distribution of B. thienemanni eastwards in Europe by about 1,440 kilometers. The Russian record is also the most northerly finding of the species and indicates that it could be expected to inhabit suitable habitats at more northern latitudes than previously thought likely and its discovery, at least in southern Scandinavia, would not be unexpected. Additional records can now be expected in more southern areas of the eastern and southern Palaearctic including southern Russia, the Ukraine, the Caucasus, Turkey, the Balkans and the Middle East.

Previous distribution data, from the western and southern Palaearctic, seems to indicate that the species was primarily associated with the mid to higher range of water temperatures. The new record from Russia and the two subfossil records change this perception. Ecologically, the Russian record in particular, but also the subfossil records from the lower reaches of large rivers in northern Germany and the Netherlands, demonstrates that the aquatic stages can not only tolerate much colder water temperatures than previously believed but can survive in rivers and streams which freeze in winter.

The detailed distribution given below includes two subfossil pupal records from old former (dried-up) river channels while the remaining are based on extant records. Its past occurrence in the Lower Rhine and the Grensmaas as subfossils means that it can also be found in the lower reaches (non-estuarine zone) of large rivers, where the water may be several meters deep. However, the species may now be extinct in many large deeper rivers such the Lower Rhine and the Grensmaas due to mid to late 20th century pollution. 
In the river Flesk, S. W. Ireland, the pupal exuviae are encountered in drift samples from the second week in July to about the middle of September which is the flight period for the adults. The seasonally earliest and latest European records are the 7th May (from Corsica) and the 13th October (from Bavaria in Germany) respectively but it is possible that the flight period at more southern warmer latitudes in the western Palaearctic may extend from April to November or even December.

\section{Subfossil Records of Buchonomyia thienemanni}

The dating of the subfossil records is not exact but is based on navigation charts (Klink 1983, 1985) which show a time when the particular section of the respective rivers, where the subfossils were found, were last navigable to ships and barges. In order to ensure the safety of ships and barges and their cargoes the navigation charts had to be very accurate.

GERMANY: North Rhine-Westphalia: at least 1745 or earlier, subfossil pupal remains from sediments collected by hand auger (taken on the 6 September 1983), Schenkenschanz [Schenkenschans in Dutch], old Bovenrijn (old Lower Rhine) river channel (now dry land) $\left(51^{\circ} 50^{\prime} 5^{\prime \prime} \mathrm{N}, 6^{\circ} 6^{\prime} 40^{\prime \prime} \mathrm{E}\right)$, leg. A. Klink (Klink 1983). NETHERLANDS: Limburg: circa 1900, subfossil pupal remains from sediments collected by hand auger (taken on the 29 September 1984), Itteren, old Grensmaas (border Meuse) river channel (now dry land) $\left(50^{\circ} 54^{\prime} 24^{\prime \prime} \mathrm{N}\right.$, 54' 5" E), leg. A. Klink (Klink 1985).

\section{Extant Records of Buchonomyia thienemanni}

AUSTRIA: Oberösterreich: June to September 1994, Hohlweg, on the River Ager, 3 kilometers downstream from Lake Attersee ( $\left.47^{\circ} 57^{\prime} 56^{\prime \prime} \mathrm{N}, 13^{\circ} 36^{\prime} 29^{\prime \prime} \mathrm{E}\right)$, leg. M. Hubmann; 15 September 1994, Alt Lenzing, near Lenzing, on the River Ager, 5 kilometers downstream from Lake Attersee ( $\left.47^{\circ} 58^{\prime} 18^{\prime \prime} \mathrm{N}, 13^{\circ} 37^{\prime} 9^{\prime \prime} \mathrm{E}\right)$, leg. M. Hubmann; June to September 1994, Höfer, on the River Ager, 7 kilometers downstream from Lake Attersee $\left(47^{\circ} 59^{\prime} 52^{\prime \prime} \mathrm{N}, 13^{\circ} 37^{\prime} 23^{\prime \prime} \mathrm{E}\right)$, leg. M. Hubmann; June to September 1994, Regau, on the River Ager, 17 kilometers downstream from Lake Attersee $\left(47^{\circ} 59^{\prime} 54^{\prime \prime} \mathrm{N}, 13^{\circ} 41^{\prime}\right.$ $\left.35^{\prime \prime} \mathrm{E}\right)$, leg. M. Hubmann; BELGIUM: Liège: 30 June 1994, at Remouchamps, 137 meters, on the Amblève River (50 28' 54" N, 5० 42' 26" E) (Evrard 1995); Luxembourg: 30 June 1994, 23 August 1994, at Maboge, 240 meters, on the Ourthe River $\left(50^{\circ} 10^{\prime} 2^{\prime \prime} \mathrm{N}, 5^{\circ} 38^{\prime} 47^{\prime \prime} \mathrm{E}\right)$ (Evrard 1995; Evrard and Goddeeris 1995); 30 June 1994, 23 August 1994, at La Ferme au Pont, 295 meters, on the Ourthe occidentale River $\left(50^{\circ} 6^{\prime} 26^{\prime \prime} \mathrm{N}, 5^{\circ} 37^{\prime} 41^{\prime \prime} \mathrm{E}\right)$ (Evrard 1995; Evrard and Goddeeris 1995); CORSICA: 8 July 1995, bridge on road D84 at 840 meters, Golo River ( $42^{\circ} 23^{\prime} 0^{\prime \prime} \mathrm{N}, 9^{\circ} 8^{\prime} 16^{\prime \prime} \mathrm{E}$ ) (Laville and Langton 2002); 17 May 1999, bridge on road D148 at 430 meters, Fiumicicoli River, tributary of the Rizzanèse River $\left(41^{\circ} 39^{\prime}\right.$ $30^{\prime \prime} \mathrm{N}, 9^{\circ} 2^{\prime} 43^{\prime \prime} \mathrm{E}$ ) (Laville and Langton 2002); 21 May 1999 , bridge on road D506 at 160 meters, $4 \mathrm{~km}$ upstream from Folelli, Fium Alto River ( $42^{\circ} 26^{\prime} 42^{\prime \prime}$ N, $9^{\circ} 28^{\prime} 14^{\prime \prime}$ E) (Laville and Langton 2002); CZECH REPUBLIC: Bohemia: 31 August 2014, circa $0.5 \mathrm{~km}$ south of road bridge in Lochovice at $314 \mathrm{~m}$ a.s.l., next to the soccer field, west bank of the Litavka River, Brdy Mountains, $49^{\circ} 50^{\prime} 54^{\prime \prime} \mathrm{N}$, $13^{\circ} 58^{\prime} 53^{\prime \prime} \mathrm{E}$, leg. D. Vondrák (Ashe et al. in press); Moravia: 21 August 2014, circa $1.2 \mathrm{~km}$ north of Hnanice, 50 meters downstream of footbridge, south bank of the River Dyje, Podyjí National Park, 48 $48^{\circ} 39^{\prime \prime} \mathrm{N}, 15^{\circ} 58^{\prime}$ $40^{\prime \prime}$ E, leg. P. Ashe \& J. Moubayed-Breil (Ashe et al. in press); FRANCE: Aisne: 20 July 2008, Guignicourt, l'Aisne River ( $\left.49^{\circ} 25^{\prime} 49^{\prime \prime} \mathrm{N}, 3^{\circ} 58^{\prime} 11^{\prime \prime} \mathrm{E}\right)$, leg. A. Klink; 21 July 2008, Lesquielles-Saint-Germain, l'Oise River $\left(49^{\circ} 55^{\prime} 39^{\prime \prime} \mathrm{N}, 3^{\circ} 37^{\prime} 2^{\prime \prime} \mathrm{E}\right)$, leg. A. Klink; Aube: 23 July 2008, Bayel, l'Aube River (48 11' 54" N, 4 46' 49" E), leg. A. Klink; Aveyron: 22 September 1977, 2 km downstream from Entraygues, $223 \mathrm{~m}$, upper River Lot $\left(44^{\circ} 38^{\prime}\right.$ $32^{\prime \prime} \mathrm{N}, 2^{\circ} 33^{\prime} 45^{\prime \prime} \mathrm{E}$ ) (Laville 1979 sub Eurycnemus crassipes (Meigen); Laville, 1981); 22 September 1977, Station 14 , Estaing at $320 \mathrm{~m}$, upper River Lot $\left(44^{\circ} 33^{\prime} 11^{\prime \prime} \mathrm{N}, 2^{\circ}\right.$ 40' 18" E) (Laville 1981); 22 September 1977, Station 13, Saint-Côme d'Olt at $351 \mathrm{~m}$, upper River Lot $\left(44^{\circ} 30^{\prime}\right.$ $47^{\prime \prime} \mathrm{N}, 2^{\circ} 48^{\prime}$ 58" E) (Laville 1981); 22 September 1977, Station 11, Pomayrols at $443 \mathrm{~m}$, upper River Lot $\left(44^{\circ} 28^{\prime}\right.$ $4^{\prime \prime} \mathrm{N}, 3^{\circ} 1^{\prime}$ 21" E) (Laville 1981); Meuse: 7 September 1992, Les Monthairons, La Moyenne Meuse River $\left(51^{\circ}\right.$ $50^{\prime} 14^{\prime \prime} \mathrm{N}, 6^{\circ}$ 6' 30" E), leg. A. Klink; Yonne: 7 May 2009, Annay-sur-Serein, Le Serein River $\left(47^{\circ} 43^{\prime} 38^{\prime \prime} \mathrm{N}, 3^{\circ} 57^{\prime}\right.$ $31^{\prime \prime}$ E), leg. A. Klink; 24 July 2008, Mailly-la-Ville, l'Yonne

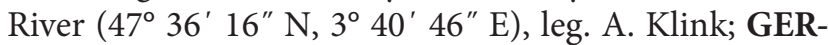
MANY: Bavaria: July-August 1980-1982, Poing, upper River Alz, outflow of Chiemsee ( $47^{\circ} 58^{\prime} 17^{\prime \prime} \mathrm{N}, 12^{\circ} 30^{\prime}$ 19" E) (Caspers 1983); July-August 1980-1982, Höllthal, upper River Alz, outflow of Chiemsee ( $47^{\circ} 58^{\prime} 39^{\prime \prime} \mathrm{N}, 12^{\circ}$ 30' 17" E) (Caspers 1983); 29 July 1983, 13 October 1983, Höllthal, upper River Alz, outflow of Chiemsee ( $47^{\circ} 58^{\prime}$ $39^{\prime \prime} \mathrm{N}, 12^{\circ} 30^{\prime} 17^{\prime \prime}$ E) (Reiss 1984); July-August 19801982, Altenmarkt, upper River Alz, outflow of Chiemsee (48 $0^{\prime} 14^{\prime \prime} \mathrm{N}, 12^{\circ} 31^{\prime}$ 52" E) (Caspers 1983); 29 July 1983, Pullach, just north of Seebruck, upper River Alz, outflow of Chiemsee ( $\left.47^{\circ} 57^{\prime} 7^{\prime \prime} \mathrm{N}, 12^{\circ} 28^{\prime} 48^{\prime \prime} \mathrm{E}\right)$, leg. E. G. Burneister; 23 July 1982, 11 September 1982, 26 September 1982, 7 July 1983, 8-10 July 1983, 17 August 1983, Schöngeising, River Amper, outflow of Ammersee ( $48^{\circ}$

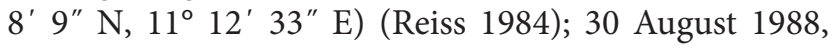
Neuhimmelreich, River Amper, outflow of Ammersee $\left(48^{\circ} 14^{\prime} 44^{\prime \prime} \mathrm{N}, 11^{\circ} 23^{\prime} 40^{\prime \prime} \mathrm{E}\right)$, leg. M. Hieber; 5 July 1984 , Mühltal, Würm River, outflow of Starnberger See $\left(48^{\circ} 1\right.$ $58^{\prime \prime} \mathrm{N}, 11^{\circ} 21^{\prime} 32^{\prime \prime}$ E), leg. G. Wyrwa; 9 August 1997, Burghausen, lower Salzach River ( $48^{\circ} 9^{\prime} 59^{\prime \prime} \mathrm{N}, 12^{\circ} 50^{\prime}$ 20" E), leg. S. Michiels, (Michiels 1999); Hessen: $3 \mathrm{Au}-$ gust 1953, spring region of the River Fulda, 800 meters, Wasserkuppe $\left(50^{\circ} 29^{\prime} 36^{\prime \prime} \mathrm{N}, 9^{\circ} 56^{\prime} 39^{\prime \prime} \mathrm{E}\right)$, leg. E. J. Fittkau (Fittkau 1955); GREAT BRITAIN: England: Devon: 15 July 1977, Bickleigh, River Exe SS 936071 (50 51 ' 12" 
N, 330'47" W), leg. R. Wilson (Murray and Ashe 1981); no date, probably Summer 1977, Bampton, River Exe SS 953205, (50 $\left.58^{\prime} 27^{\prime \prime} \mathrm{N}, 3^{\circ} 29^{\prime} 38^{\prime \prime} \mathrm{W}\right)$; no date, probably Summer 1977, Exebridge, River Exe SS 930245 (500' $\left.34^{\prime \prime} \mathrm{N}, 3^{\circ} 31^{\prime} 35^{\prime \prime} \mathrm{W}\right)$; no date, probably Summer 1977, Tiverton, River Exe SS 955120 (5053' 52" N, 329' 23" W); Worcestershire: 23 June 2007, Huntsfield Cottage, Eymore Wood at the NE corner of the Wyre Forest, SO 773796 (52 $24^{\prime} 50^{\prime \prime} \mathrm{N}, 2^{\circ} 20^{\prime} 6^{\prime \prime} \mathrm{W}$ ), M. Blythe (adult male probably from the nearby River Severn, collected at light on white sheet); Wales: Powys: no date, probably Summer-Autumn circa 1977 to 1982, Llangynidr, River Usk SO 152202 (51 ${ }^{\circ} 52^{\prime} 28^{\prime \prime} \mathrm{N}, 3^{\circ} 13^{\prime}$ 59” W), leg. R. Wilson; Monmouthshire: no date, probably Summer-Autumn circa 1977 to 1982 , Llantrisant, River Usk ST 388963 (51 ${ }^{\circ} 39^{\prime} 43^{\prime \prime} \mathrm{N}, 2^{\circ} 53^{\prime} 8^{\prime \prime} \mathrm{W}$ ), leg. R. Wilson; no date, probably Summer-Autumn circa 1977 to 1982, Usk, River Usk SO 371021 (5142' 50" N, 2 54' 41" W), leg. R. Wilson (Reiss 1984); IRAN: Isfahan: August-November 1978, bridge in Isfahan City, Zayande River, $1590 \mathrm{~m}$ (32 $38^{\prime} 35^{\prime \prime} \mathrm{N}, 51^{\circ} 39^{\prime} 30^{\prime \prime} \mathrm{E}$ ), leg. C. Dowling (Dowling 1980); IRELAND: Carlow: 28 July 1981, Kilcarry Bridge, River Slaney S893624 (52 $42^{\prime} 24^{\prime \prime} \mathrm{N}, 6^{\circ} 40^{\prime} 46^{\prime \prime} \mathrm{W}$ ), B. Hayes (Murray et al. 2013); Cork: 31 August 1981, Killavullen, River Blackwater W648998 (52 ${ }^{\circ}$ ' 56" N, 8 30' 56" W), B. Hayes (Murray et al. 2013); Kerry: 26 July 1974, 19 July 1978, 20 July 2001, White Bridge, River Flesk V987904 (52 $3^{\prime} 23^{\prime \prime} \mathrm{N}, 9^{\circ} 28^{\prime} 42^{\prime \prime} \mathrm{W}$ ) (Murray et al. 2013); July to September 1978 and 1979, downstream of New Bridge, River Flesk V963885 (52 $2^{\prime} 52^{\prime \prime} \mathrm{N}, 9^{\circ} 30^{\prime}$ $37^{\prime \prime}$ W), P. Ashe (Murray et al. 2013); July to September 1978 and 1979, circa $0.5 \mathrm{~km}$ upstream of Lough Leane, River Flesk V943894 (52²' 34" N, 9 30' 51" W), P. Ashe (Murray et al. 2013); July to September 1978 and 1979, August 1981, downstream of White Bridge, River Flesk V987900 (52 $\left.3^{\prime} 23^{\prime \prime} \mathrm{N}, 9^{\circ} 28^{\prime} 42^{\prime \prime} \mathrm{W}\right)$, P. Ashe (Murray et al. 2013); July to September 1978 and 1979, Garries

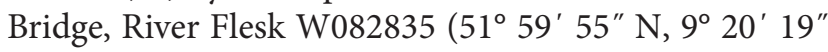
W), P. Ashe (Murray et al. 2013); July to September 1978 and 1979, upstream of Clydagh Bridge, Clydagh River W114826 (51 59' 19" N, 9 17' 28" W), P. Ashe (Murray et al. 2013); Kildare: 17 July 1983, Millicent Bridge, Sallins, River Liffey N881245 (53 $\left.15^{\prime} 51^{\prime \prime} \mathrm{N}, 6^{\circ} 40^{\prime} 50^{\prime \prime} \mathrm{W}\right)$, B. Hayes (Murray et al. 2013); July 2006, Kilcullen, River Liffey N841097 (53 7' 54" N, 6 44' 34" W), J.-R. Baars (Murray et al. 2013); Kilkenny: 28 August 1981, Norelands Bridge, River Nore S547436 (52 $32^{\prime} 32^{\prime \prime} \mathrm{N}, 7^{\circ} 11^{\prime}$ $36^{\prime \prime}$ W), B. Hayes (Murray et al. 2013); August 1982, Norelands Bridge, River Nore S547436 (52 32' 32" N, $7^{\circ}$ $11^{\prime} 36^{\prime \prime}$ W), P. Ashe (Ashe 1985, Murray et al. 2013); 28 August 1981, Brownsbarn Bridge, River Nore S618391 (52 $\left.30^{\prime} 1^{\prime \prime} \mathrm{N}, 7^{\circ} 5^{\prime} 30^{\prime \prime} \mathrm{W}\right)$, B. Hayes (Murray et al. 2013); Mayo: 18 August 1983, Bangor Erris, Owenmore River

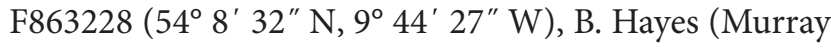
et al. 2013); 30 August 1982, Cloongullaun, River Moy G348016 (535 57' 30" N, 8 59' 39" W), B. Hayes (Murray et al. 2013); 29 August 1982, Ballylahan, River Moy

M276994 (535 56' 18" N, 9 6' 8" W), B. Hayes (Murray et al. 2013); Waterford: 31 August 1981, Ballyduff, River Blackwater W964992 (52 8' 40" N, 8 3' 9" W), B. Hayes (Murray et al. 2013); 31 August 1981, Lismore, River Blackwater X047988 (52 $\left.{ }^{\circ} 8^{\prime} 28^{\prime \prime} \mathrm{N}, 7^{\circ} 55^{\prime} 53^{\prime \prime} \mathrm{W}\right)$, B. Hayes (Murray et al. 2013); ITALY: Emilia: 3 July 2002, 17 September 2002, near Compiano at 519 m a.s.l.,

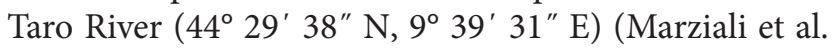
2004); Lombardy: 26 June 2002, near the village of Comazzo at $99 \mathrm{~m}$ a.s.l., Adda River $\left(45^{\circ} 26^{\prime} 11^{\prime \prime} \mathrm{N}, 9^{\circ} 28^{\prime} 11^{\prime \prime}\right.$ E) (Marziali et al. 2004); LUXEMBOURG: 28 August 1983, Echternach, River Sûre (4949' 9" N, 60 24' 21" E), A. Klink (Klink 1983); MOROCCO: Chefchaouène: June to October 2003, Akoumi at 400 meters, Oued Kelaa, Parc National de Talassemtane $\left(35^{\circ} 14^{\prime} 26^{\prime \prime} \mathrm{N}, 5^{\circ} 10^{\prime}\right.$ 39" E) (Kettani et al. 2010); RUSSIA: Moskovskaya Oblast: 18 July 1995, LIS2 (site 2), Little Istra River, circa 66.7 kilometers west of Moscow, $55^{\circ} 50^{\prime} 51^{\prime \prime} \mathrm{N}, 36^{\circ} 35^{\prime}$ 56" E, leg. N. H. Crisp; SLOVAKIA: Žilina: 21 July 1979, below the village of Rajecká Lesná at $480 \mathrm{~m}$, Rajčianka submontane brook, 49 $03^{\prime} 25^{\prime \prime} \mathrm{N}, 18^{\circ} 37^{\prime} 21^{\prime \prime} \mathrm{E}$, leg. P. Bitušík (Bitušík 1987; Bitušík and Ashe in press); 17 July 1994, below the village of Varín at $353 \mathrm{~m}$, Varínka submontane brook, 49 $11^{\prime} 48^{\prime \prime} \mathrm{N}, 18^{\circ} 52^{\prime} 14^{\prime \prime} \mathrm{E}$, leg. P. Bitušík (Bitušík and Ashe in press); Levice: 3 July 2003, close to the village of Jur at $142 \mathrm{~m}$, River Hron, 48 $07^{\prime}$ $47^{\prime \prime} \mathrm{N}, 18^{\circ} 36^{\prime} 41^{\prime \prime} \mathrm{E}$, leg. P. Bitušík (Bitušík et al. 2006; Bitušík and Ashe in press); Sered: 10 June 2009, above the reservoir of Králová at 120 m, River Váh, 48 $15^{\circ} 40^{\prime \prime}$ $\mathrm{N}, 17^{\circ} 46^{\prime} 25^{\prime \prime} \mathrm{E}$, leg. S. Ščerbaková (Bitušík and Ashe in press); SPAIN: Andalusia: 1987-1988, site GQ5, 740 meters, Guadalquivir River ( $\left.37^{\circ} 56^{\prime} 45^{\prime \prime} \mathrm{N}, 2^{\circ} 55^{\prime} 34^{\prime \prime} \mathrm{E}\right)$ (Calle Martinez et al. 1995); 1987-1988, site GQ7, 640 meters, Guadalquivir River ( $38^{\circ} 10^{\prime} 44^{\prime \prime} \mathrm{N}, 2^{\circ} 50^{\prime} 8^{\prime \prime} \mathrm{E}$ ) (Calle Martinez et al. 1995); Galicia: Summer-Autumn 1986, Santiso at 320 meters, Ulla River $\left(42^{\circ} 51^{\prime} 3^{\prime \prime} \mathrm{N}, 8^{\circ}\right.$ 4' 18" E) (Cobo and Gonzáles 1990).

\section{Ecology of Buchonomyia thienemanni}

The single 4th instar larva of $B$. thienemanni from S. W. Ireland, (originally believed to be a 3rd instar larva Ashe 1995), was found - in an elongated sinuous fixed sand and silk case on the upper side of a large stone in a shallow riffle area of the River Flesk. An updated larval diagnosis of the genus Buchonomyia is given in Cranston and Ashe (2013). It has been suggested previously that the immatures of $B$. thienemanni may be associated with a species of Trichoptera (Ashe and O'Connor 2002).

Larvae of $B$. thienemanni are here considered incapable of constructing the case in which it was found. Furthermore, morphological features such as: (1) the short, reduced and laterally projecting posterior parapods, (2) the strongly reduced anterior parapods with only a few weak claws, (3) the three pairs of large anal gills which are larger than the posterior parapods, (4) the small head relative to the body size which is triangular and narrowed 
anteriorly and (5) the white coloured body all indicate that the larva is not free-living and appears to be incapable of clinging to or crawling on the substrate. Free-living larvae are coloured (often green or yellow, never white) and less visible, have well developed anterior and posterior parapods with numerous claws, a normal sized head and smaller anal gills and they can easily cling to or move across underwater substrates.

Many chironomids produce silk from the mouth which is manipulated and extruded with the assistance of serrated claws on the anterior parapods. There is no indication of silk production by B. thienemanni and the reduced size of the head and the weakly developed anterior parapods with few claws implies an inability to manipulate silk, sand grains or other construction materials to create a larval retreat. Consequently some other invertebrate, most likely an insect larva, must have constructed the larval retreat in which $B$. thienemanni was found. Features of $B$. thienemanni which indicate an ectoparasitic habit include its discovery in a case which it could not construct, the white body colour, the small triangular-shaped head, the enlarged anal gills and reduced anterior and posterior parapods with weakly developed claws.

Several chironomid taxa which are ectoparasitic on Trichoptera have modifications on the anterior margin of the pupal cephalothorax (Figs. 1A-C, D) in the form of chitinised projections (i.e. Cardiocladius albiplumus Sæther, species of Eurycnemus van der Wulp, Collartomyia hirsuta (Goetghebuer), some species of Polypedilum (Cerobregma Sæther and Sundal)). These chitinised projections enable the chironomid pupa to break through and escape from the tough robust pupal retreat constructed by the trichopteran host. The positions of these chitinised projections on the cephalothorax are variable and include the dorsal margin (Collartomyia hirsuta), the dorso-lateral corner (Eurycnemus spp.), the medio-lateral margin (Cardiocladius albiplumus) and in the ventro-

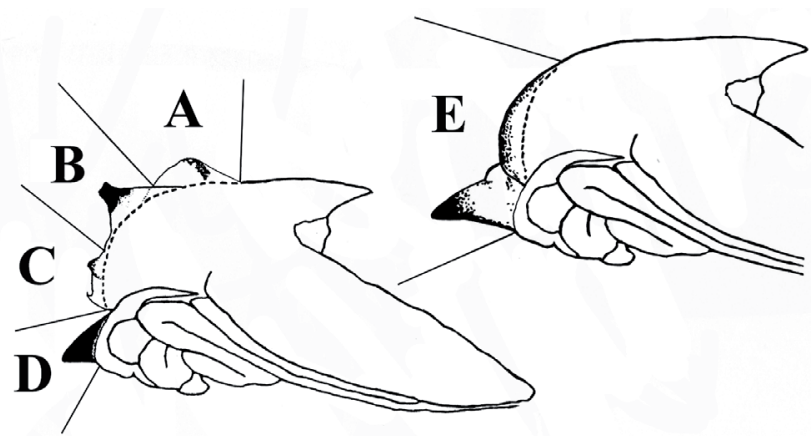

Fig. 1 Side view of the cephalothorax of a generalised chironomid pupa superimposed with the chitinised projections of five different genera (not necessarily to the same scale). A, Collartomyia hirsuta (Goetghebuer); B, Eurycnemus crassipes (Meigen); C, Cardiocladius albiplumus Sæther; D, Buchonomyia thienemanni; E, Polypedilum (Cerobregma) kamotertium Sasa. A-D modified from Ashe and O'Connor (2002, Fig. 1), E chitinised projection redrawn from Kobayashi et al. (2003, Fig. 3B) superimposed on the outline of a generalised chironomid pupa from Ashe and O'Connor (2002). The heavy dashed line shows the expected outline in a typical chironomid where chitinised projections are lacking. lateral region, forwardly directed fused cephalic tubercles in Polypedilum (Cerobregma) kamotertium Sasa.

The modifications on the cephalothorax cannot function on their own but also need additional structures on the chironomid pupal abdomen to gain leverage to enable the chitinised projections to function and pierce the walls of the trichopteran case thereby effecting the escape of the chironomid pupa. These abdominal modifications include the long spines on the tergites of Eurycnemus spp. and Cardiocladius albiplumus and the strongly developed anal combs on tergite VIII in P. (C.) kamotertium and in Collartomyia hirsuta. Such modifications on the pupal abdomen are not unique to species associated with Trichoptera but they are significant when combined with the presence of chitinised projections on the cephalothorax.

The chitinised projections, on the base of the antennal sheaths, in B. thienemanni (Fig. 1D) indicate a trichopteran association. Observations on a live pupa of $B$. thienemanni from a kick sample in the River Flesk (Ireland) shows that it orientates itself with the dorsal surface uppermost and twists from side to side in a snake-like motion whereas most chironomid pupae flex the abdomen in an up and down motion. It is postulated that the distinctive lateral spines on the pupal abdomen (Fig. 2, Murray and Ashe 1981, Fig. 3), a unique feature in Chironomidae, are used in conjunction with the chitinised projections and the snake-like side to side motion of the pupa to enable $B$. thienemanni to escape from a trichopteran pupal case. The above data on chironomids which are known to be ectoparasitic on Trichoptera combined with the known ecology and certain features of the larvae and pupae of B. thienemanni indicate that it also is ectoparasitic on Trichoptera. Assuming that this is the case, is it possible to identify a likely trichopteran host?

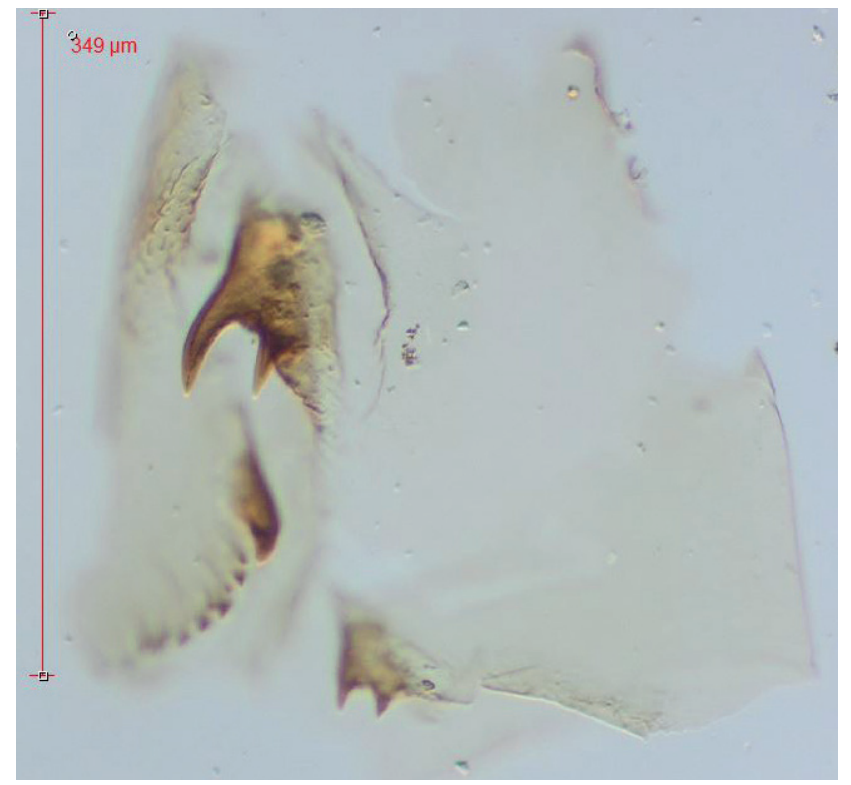

Fig. 2 Photograph of a pseudofossil fragment of the side (pleurite) of an abdominal pupal segment of $B$. thienemanni showing the characteristic lateral spines. The specimen in the photograph is from Schenkenschanz in Germany. Photo A. Klink. 


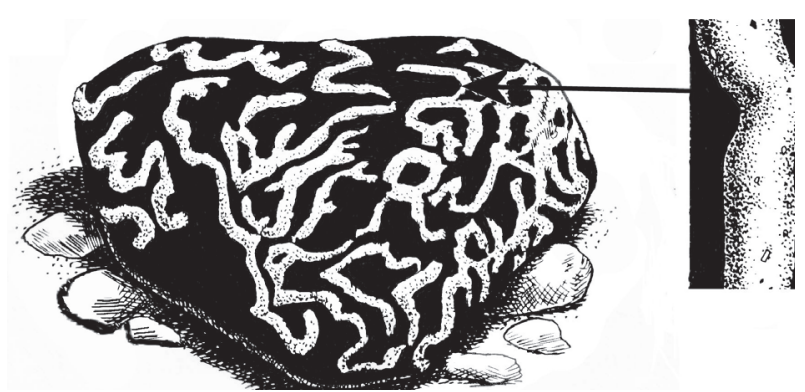

Fig. 3 Larval galleries of Psychomyia sp. (Psychomyiidae). Modified from Wiggins (1977).

Since the postulated trichopteran host of $B$. thienemanni is unknown, it is necessary to consider the available data to determine if a likely candidate can be identified. The presumed trichopteran host species of B. thienemanni, assuming only one host, must: (A) occur in Ireland, (B) be widespread in Europe, (C) occur in North Africa and (D) occur in Iran. The Trichoptera in Europe are represented by 1,049 valid species (Malicky 2011) of which 151 species are known from Ireland (O'Connor and Nelson 2012; O'Connor and O'Connor 2013). This immediately reduces the number of potential host species to 151 . We can reduce this number of 151 to 123 if we exclude all the Irish species which do not occur in rivers and streams.

The larvae of some Trichoptera are free-living, many construct elaborate transportable cases and some construct loosely formed feeding retreats - the vast majority of species are found on the underside of stones and other objects. The presumed trichopteran host must occur not only in the upper and middle reaches of rivers but must also be capable of surviving in the non-estuarine lower reaches of very large, slow-flowing, rivers, which may be several meters deep, such as the Lower Rhine and the Grensmaas (although due to past human impacts from pollution it may now be extinct in these two sections of river). So far as we know, only members of the family Psychomyiidae (Gallery Building Caddisflies) within the Trichoptera are associated with the upperside of solid objects (stones, submerged wood, etc.) where the larvae construct long sinuous galleries, firmly affixed to the surface, which increase in length as the larvae grow (Fig. 3). The 4 th instar larva of $B$. thienemanni from the River Flesk was found is a sinuous larval gallery on the upperside of a large stone which suggests that the most likely host is a member of the Psychomyiidae. In Europe there are three genera of Psychomyiidae, i.e. Lype McLachlan, Psychomyia Latreille and Tinodes Leach. Of these, the galleries of Psychomyia and Tinodes are found on stones but Lype is mostly associated with submerged wood and we exclude the latter from further consideration. In sites where $B$. thienemanni occurs and which are also well investigated for Trichoptera the one species which is consistently always present is Psychomyia pusilla (Fabricius) which also occurs in outflow rivers from lakes and is also reported as subfossils from the same sites where subfossils of $B$. thienemanni were found. The distribution of $P$. pusilla is wide-ranging and includes all the geographical areas where $B$. thienemanni is found as well as the upper, middle and lower (non-estuarine) reaches of large rivers. The available evidence indicates that P. pusilla is the most likely host but whether or not this is correct can only be confirmed by finding the larvae or pupae of $B$. thienemanni within the larval galleries or pupal retreats of the trichopteran. We include maps showing the distribution of B. thienemanni (Fig. 4) and P. pusilla (Fig. 5) in Ireland. A possible explanation for the presence of the peculiar, short, laterally projecting posterior parapods is that they may be used alternatively against the inner walls of the larval gallery to enable the B. thienemanni larva to propel itself forwards or backwards within the gallery.

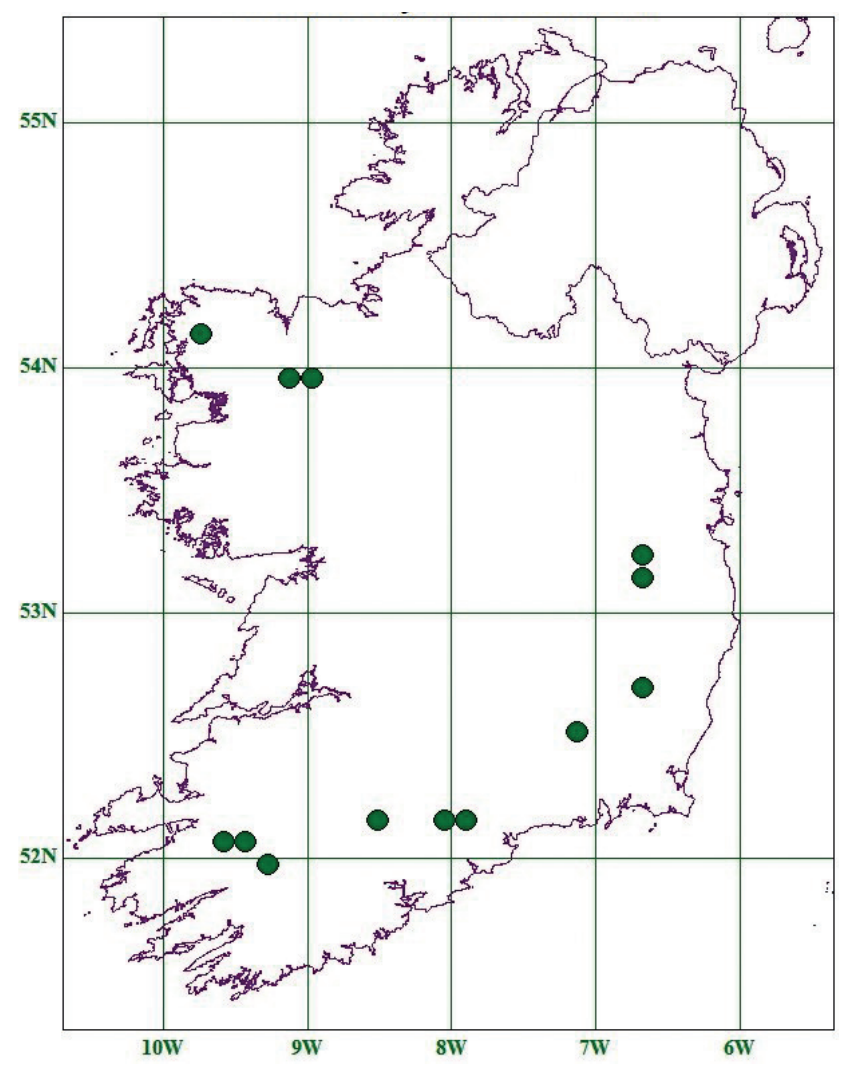

Fig. 4 Distribution of Buchonomyia thienemanni in Ireland.

In a study on $P$. (C.) kamotertium Kobayashi et al. (2003) found that: (i) there is only one chironomid larva in each trichopteran pupal case; (ii) the chironomid larva is orientated in the same direction as the trichopteran; (iii) the prepupal trichopteran is not harmed by the chironomid larva; (iv) after the trichopteran pupates a single wound hole was detected on the underside of the prothorax and (v) when the chironomid had finished feeding there was usually only chitinised fragments of the trichopteran left or occasionally a few remaining posterior segments, after $P$. (C.) kamotertium has pupated. 


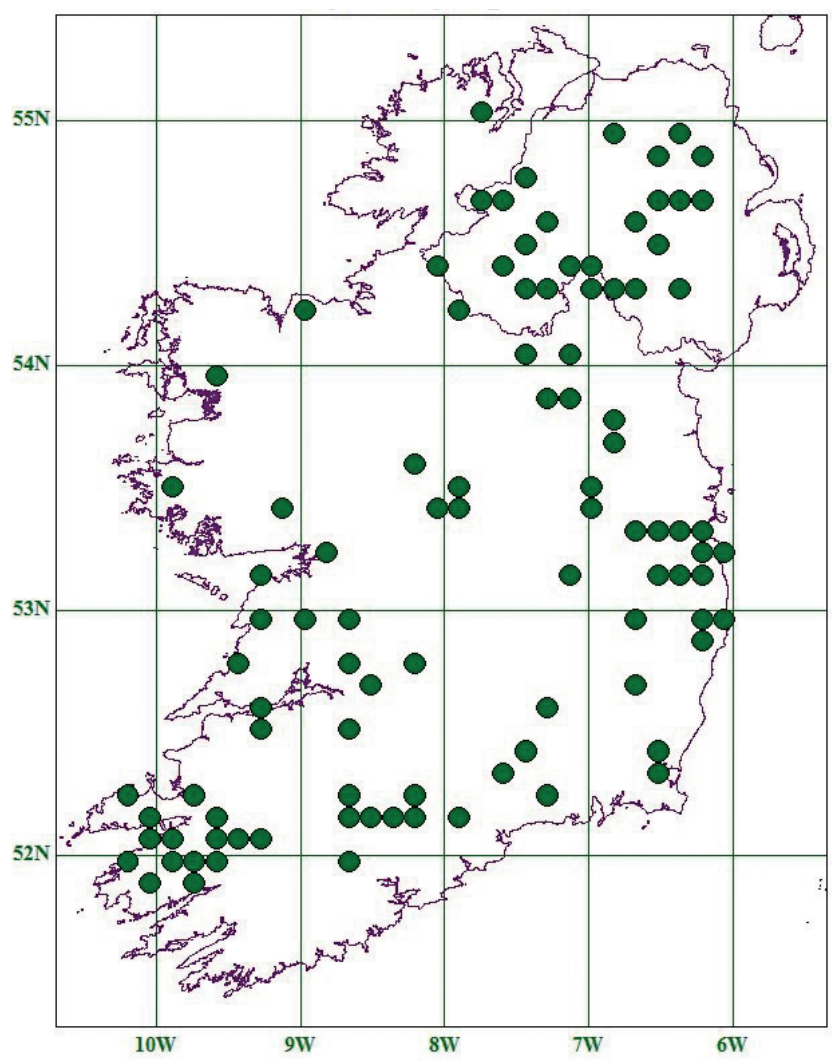

Fig. 5 Distribution of Psychomyia pusilla in Ireland.

All the above points except point (iv) have been observed in Eurycnemus crassipes but it is believed, as in point (iv), that after pupation of the host it is attacked by the chironomid larva - a similar scenario can be expected in B. thienemanni.

In the pupa of $B$. thienemanni the downwardly directed chitinised projections, located on the base of the antennal sheaths, are on the ventro-lateral corner. A possible explanation for this position can be provided by considering Eurycnemus crassipes whose ecology is better known. In E. crassipes the chitinised projections are located on the dorso-lateral corner while the trichopteran host is Hydropsyche siltalai Döhler, whose pupal retreats are found on the underside of stones. Since B. thieneman$n i$ is believed to be associated with a trichopteran host which occurs on the upperside of stones it seems logical that the chitinised projections should be located on the ventro-lateral corner which is the opposite position to that found in E. crassipes if we assume that a similar means of escape is used by the pupae of both genera. Only further investigation will prove whether or not this explanation is correct.

\section{Acknowledgements}

We are grateful to Martin Spies, Zoologische Staatssammlung Munich (ZSM), Germany, for data from specimens and correspondence relating to $B$. thienemanni in the ZSM collections. Dr Alexander Klink, Hydrobi- ologisch Adviesburo Klink, Wageningen, Netherlands kindly provided data on the subfossil records, some extant records (from northern France and Luxembourg) and the photograph of the subfossil pupal fragment of B. thienemanni. We also wish to thank Dr Len Ferrington, University of Minnesota, U. S. A., for data on the record from Russia and Mick Blythe, Stourport-on-Severn, England, for the Worcestershire record. The senior author would also like to thank Michael Hubmann, Arge Limnologie, Innsbruck, Austria, who provided details on several Austrian records in correspondence from 1995 and Dr Joel Moubayed-Breil, Montpellier, France, for his opinion on aspects of the ecology of $B$. thienemanni.

\section{REFERENCES}

Ashe P (1985) A larval diagnosis for the subfamily Buchonomyiinae and the genus Buchonomyia with a description of the 1st instar larva of Buchonomyia thienemanni Fittkau (Diptera, Chironomidae). In: Fittkau EJ (ed) Beiträge zur Systematik der Chironomidae, Diptera. Spixiana Suppl 11, pp. 143-148.

Ashe P (1995) Description of a late-instar larva of Buchonomyia thienemanni Fittkau and further data on its ecology with diagnoses for the subfamily Buchonomyiinae and the genus $\mathrm{Bu}$ chonomyia (Diptera: Chironomidae). In: Cranston PS (ed) Chironomids: from genes to ecosystems, Proceedings of the 12th International Symosium on Chironomidae, Canberra, January 23-26, 1994. CSIRO Australia, East Melbourne, pp. 425-429.

Ashe P, O'Connor JP (2002) A review of the known associations, commensal, phoretic and ectoparasitic, involving the aquatic stages of Chironomidae (Diptera) with Trichoptera. In: Proceedings of the 10th International Symposium on Trichoptera. Nova Suppl Ent 15, pp. 467-480.

Ashe P, Moubayed-Breil J, Vondrák D (in press) First records of Buchonomyia thienemanni Fittkau (Diptera: Chironomidae) from the Czech Republic. Chironomus 27: xxx.

Bitušík P (1987) To the knowledge of Chironomidae (Diptera) of Czechoslovakia. Biológia (Bratislava) 42: 207-211.

Bitušík P, Ashe P (in press) Data on Buchonomyia thienemanni Fittkau (Diptera: Chironomidae) from Slovakia. Chironomus 27: Xxx.

Bitušík P, Svitok M, Dragúňová M (2006) The actual longitudinal zonation of the River Hron (Slovakia) based on chironomid assemblages (Diptera, Chironomidae). Acta Univ Carol Biol 50: 5-17.

Calle Martinez D, Vilchez Quero A, Casas Jimenez JJ (1995) Chironomids (Diptera) of the Upper-Guadalquivir (Sierra de Cazorla, Southern Spain). Ann Limnol 31: 201-213.

Caspers N (1983) Die Chironomiden der Oberen Alz (Diptera, Nematocera). Nachrichtenbl Bayer Ent 32: 97-108.

Cobo F, González MA (1990) Las comunidades de quironómidos (Diptera: Chironomidae) del río Ulla (NW de España). Limnetica 6: 109-118.

Cranston PS, Ashe P (2013) The larvae of Buchonomyiinae (Diptera: Chironomidae) of the Holarctic Region - Keys and diagnoses. In: Andersen T, Cranston PS, Epler JH (eds) The larvae of Chironomidae (Diptera) of the Holarctic region - Keys and diagnoses. Insect Syst and Evol Suppl 66: 25-28.

Dowling C (1980) Preliminary investigations on the Chironomidae (Insecta, Diptera) from some lotic environments in Iran. In: Murray DA (ed) Chironomidae. Ecology, systematics, cytology 
and physiology. Proc. 7th Int. Symp. Chironomidae, Dublin, August 1979. Pergamon Press, Oxford, pp. 131-137.

Evrard M (1995) The chironomid fauna of the Ourthe basin, Belgium: additions to the Belgian check-list of Chironomidae (Diptera). Ann Limnol 31: 215-221.

Evrard M, Goddeeris B (1995) Notes on the presence of a subfamily of Chironomidae (Diptera) new to the fauna of Belgium. Bull Soc R Belge Entomol 131: 493-498.

Fittkau EJ (1955) Buchonomyia thienemanni n. gen. n. sp. Chironomidenstudien IV (Diptera; Chironomidae). Beitr Ent 5: 403-414.

Kettani K, Belqat B, El Houari H (2010) Les Chironomidés (Diptera, Nematocera) du Parc National de Talassemtane (Rif, Maroc) : faunistique et biogéographie. In: Himmi, O (ed) Actes de la CIFE VI, Travaux de l'Institut Scientifique, Série Zoologie, Rabat, $\mathrm{N}^{\circ} 47$, Tome I, pp. 67-72.

Klink A (1983) Studie over de toepasbaarheid van palaeolimnologish onderzoek in riviersedimenten. Een middel om biologische beoordeeling van rivieren te onderbouvwen? (Study on the applicability of palaeontological investigation in river sediments. A means to support the biological evaluation of rivers?). Rapporten en Mededelingen (Hydrobiologisch Adviesburo) 7: $1-27+11$. Wageningen.

Klink A (1985) Hydrobiologie van de Grensmaas. Huidig funktioneren, potenties en bedreigingen. Deel 1 Overzicht van het Onderzoek en Konklusies. Deel 2 Gegevens-Bestand. Rapporten en Mededelingen (Hydrobiologisch Adviesburo) 7: 1-38; 1-111. Wageningen.

Kobayashi T, Ohtaka A, Takahashi T (2003) The second record of ectoparasitic Chironomidae on Trichoptera from Japan, Polypedilum (Cerobregma) kamotertium Sasa, 1989 (Insecta, Diptera, Chironomidae, Chironomini). Spixiana 26: 83-91.

Laville H (1979) Etude de la dérive des exuvies nymphales des chironomides au niveau du confluent Lot-Truyere. Ann Limnol 15: $155-180$.

Laville H (1981) Récoltes d'exuvies nymphales de Chironomides (Diptera) dans le Haut-Lot, de la source (1295 m), au confluent de la Truyère (223 m). Ann Limnol 17: 255-289.
Laville H, Langton P (2002) The lotic Chironomidae (Diptera) of Corsica (France). Ann Limnol 38: 53-64.

Malicky H (2011) Fauna Europaea: Trichoptera. In: Malicky H (ed) Fauna Europaea: Trichoptera. Fauna Europaea version 2.4. Internet database at http://www.faunaeur.org. Accessed 28 October 2014.

Marziali L, Casalegno C, Rossaro B (2004) The first record of the subfamily Buchonomyiinae (Diptera, Chironomidae) from Italy. Ital J Zool 71: 341-345.

Michiels S (1999) Die Chironomidae (Diptera) der unteren Salzach. Lauterbornia 36: 45-53.

Murray DA (1976) Buchonomyia thienemanni Fittkau (Diptera, Chironomidae), a rare and unusual species recorded from Killarney, Ireland. Entomol Gaz 27: 179-180.

Murray DA, Ashe P (1981) A description of the pupa of Buchonomyia thienemanni Fittkau, with notes on its ecology and on the phylogenetic position of the subfamily Buchonomyiinae (Diptera, Chironomidae). Spixiana 4: 55-68.

Murray DA, Ashe P (1985) A description of the adult female of Buchonomyia thienemanni Fittkau and a re-assessment of the phylogenetic position of the subfamily Buchonomyiinae (Diptera, Chironomidae. In: Fittkau EJ (ed) Beiträge zur Systematik der Chironomidae, Diptera. Spixiana Suppl 11, pp. 149-160.

Murray DA, Langton PH, O'Connor JP, Ashe P (2013) Distribution records of Irish Chironomidae (Diptera): Part 1 - Buchonomyiinae, Podonominae, Tanypodinae, Telmatogetoniinae, Diamesinae and Prodiamesinae. Bull Ir Biogeog Soc 37: 208-336.

O'Connor JP, Nelson, B (2012) An annotated checklist of the Irish Hemiptera and small orders. The Irish Biogeographical Society, Dublin.

O'Connor JP, O'Connor M (2013) Hydroptila valesiaca Schmid (Trich.: Hydroptilidae) new to Ireland with records of two other notable species. Entomol Rec J Var 125: 189-193.

Reiss F (1984) Chironomiden (Diptera, Insecta) aus dem Ampertal bei Schöngeising, Oberbayern. Mitt Zool Ges Braunau 4: 211-220.

Wiggins GB (1977) Larvae of the North American caddisfly genera (Trichoptera). University of Toronto Press, Toronto, Buffalo and London. 